\title{
Oral mite anaphylaxis by Thyreophagus entomophagus in a child: a
}

\section{case report}

\author{
Javier Iglesias-Souto시 Inmaculada Sánchez-Machín ${ }^{1}$, Víctor Iraola², \\ Paloma Poza1, Ruperto González ${ }^{1}$ and Víctor Matheu*1,3,4
}

\author{
Address: ${ }^{1}$ Consulta de Alergia Infantil, Allergy Service, Hospital Universitario NS Candelaria, S/C Tenerife, Spain, ${ }^{2}$ LETI, S.L., R \& D Department, \\ Madrid, Spain, ${ }^{3}$ Unidad de Investigación, Hospital Universitario NS Candelaria, S/C Tenerife, Spain and ${ }^{4}$ Department of Clinical Sciences-Division \\ IV, Lund University, Sweden \\ Email: Javier Iglesias-Souto - javieriglesiassouto@yahoo.es; Inmaculada Sánchez-Machín - zerupean@hotmail.com; \\ Víctor Iraola - viraola@leti.es; Paloma Poza - pozaguedes@hotmail.com; Ruperto González - glezruperto@hotmail.com; \\ Víctor Matheu* - victor.matheu@med.lu.se \\ * Corresponding author
}

Published: 25 November 2009

Clinical and Molecular Allergy 2009, 7:10 doi:10.1186/1476-7961-7-10
Received: 20 October 2009

Accepted: 25 November 2009

This article is available from: http://www.clinicalmolecularallergy.com/content/7/1/10

(c) 2009 Iglesias-Souto et al; licensee BioMed Central Ltd.

This is an Open Access article distributed under the terms of the Creative Commons Attribution License (http://creativecommons.org/licenses/by/2.0), which permits unrestricted use, distribution, and reproduction in any medium, provided the original work is properly cited.

\begin{abstract}
Sensitization to Thyreophagus entomophagus, a storage mite, is uncommon and might produce occupational respiratory disorders in farmers. We present the first case of a child suffering anaphylaxis produced by ingestion of contaminated flour with Thyreophagus entomophagus.
\end{abstract}

Thyreophagus entomophagus is a storage mite, usually sited in farms [1], but not in house dust of households [2]. Sensitization to mite species might produce occupational respiratory disorders in farmers $[1,3]$. However, it is unusual to live in urban houses or to produce symptoms by ingestion and there is no any report of child affected.

We encountered a 13-year-old boy suffering wheals, itching and diffuse erythema, cough and wheeze immediately after ingest a home-made crêpe, prepared at home with wheat flour, which was stored in kitchen for weeks. He was treated at the Emergency Department with intravenous fluids, diphenhydramine, epinephrine, and methylprednisolone, with complete symptom resolution in 2 hours. He had a previous history of mild persistent allergic rhinoconjunctivitis and sensitization to house dust mite and facial angioedema, urticaria and bronchospasm after Ibuprofen, but not any history about food allergy. Skin prick tests (SPT) to common inhalant allergens were positive to Dermatophagoides pteronyssinus, Dermatophagoides farinae or Blomia tropicalis and negative to the remainder inhalants and foodstuffs including wheat flour. Acoustic Rhinometry showed reversible mild obstruction. Forced spirometry showed a mild obstructive pattern with values -FVC: 3.98 (97\%), FEV 2.78 (79\%), MEF 50\% 2.22 (49\%), FEF 25-75\%: 1.93 (45\%)-. Bronchodilator test showed a positive response with an improvement of $\mathrm{FEV}_{1}$ post $3.17(+13 \%)$. After written informed consent signed by patient and his mother, open oral challenge (OOC) with different foodstuffs were performed. OOC with wheat and a commercial crêpe were good tolerated. Since patient's mother brought us the culprit flour, microscopic examination was performed and revealed mite contamination by Thyreophagus entomophagus (104 mites/gram). New SPT were done showing positive reactions with Cheyletus spp. and a protein extract of Thyreophagus entomophagus (Leti, Madrid, Spain). SPT to other storage mites were negative. Specific IgE against the extract of Thyreophagus entomophagus was also demonstrated in vitro by direct specific enzyme-immune-assay (Optical Density: 0.904; Control: 0.05) and by InmunoCAP (UniCAP, Phadia): 15,2 


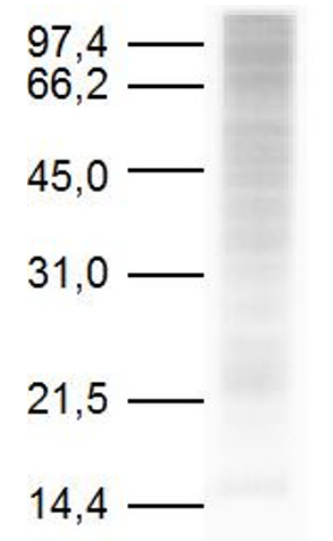

Figure I

Immunoblot of patient' serum showing IgE reactivity against the storage mite Thyreophagus enterophagus.

kU/L. Immunoblot also demonstrated IgE reactivity (figure 1).

After a new written informed consent signed by patient and his mother, specific nasal provocation test was done showing positive symptoms score after instilled Thyre- ophagus entomophagus (dilution $1 / 10 \mathrm{w} / \mathrm{v}$ ) with a drop of $30 \%$ in the minimal cross-sectional area by Acoustic Rhinometry (figure 2). Finally, after a new informed consent an open oral challenge with aspirin was done. The OOC was positive with peri-orbital angioedema.

Hidden allergens [4] in allergic individuals are still a big issue [5]. Among others, hidden live organisms inside foodstuffs can provoke episodes of anaphylaxis in sensitized patients [6]. Matsumoto et al described the first case of oral mite anaphylaxis (OMA) after eating storage-mitecontaminated food by a mite [7]. Further, some other groups have reported symptoms of asthma [8] or OMA $[9,10]$ by mite-contaminated foodstuffs. Several species of mites, such as Dermatophagoides pteronyssinus, Dermatophagoides farinae or Blomia tropicalis have been linked with the OMA $[9,11,12]$, so called Pancake syndrome. However, Thyreophagus entomophagus has been only reported by Blanco et al [9]. This is the first report of anaphylaxis by Thyreophagus entomophagus in a child. Furthermore, it is the first time that a specific nasal provocation test with Thyreophagus entomophagus has been performed.

In our patient, the culprit foodstuff was a, previously cooked, home-made crêpe, This is in line of SanchezBorges et al, who have concluded that anaphylaxis might occur after the ingestion of heated or unheated mite-contaminated foods study [13]. In same study, authors described 28 patients with anaphylaxis triggered by inges-

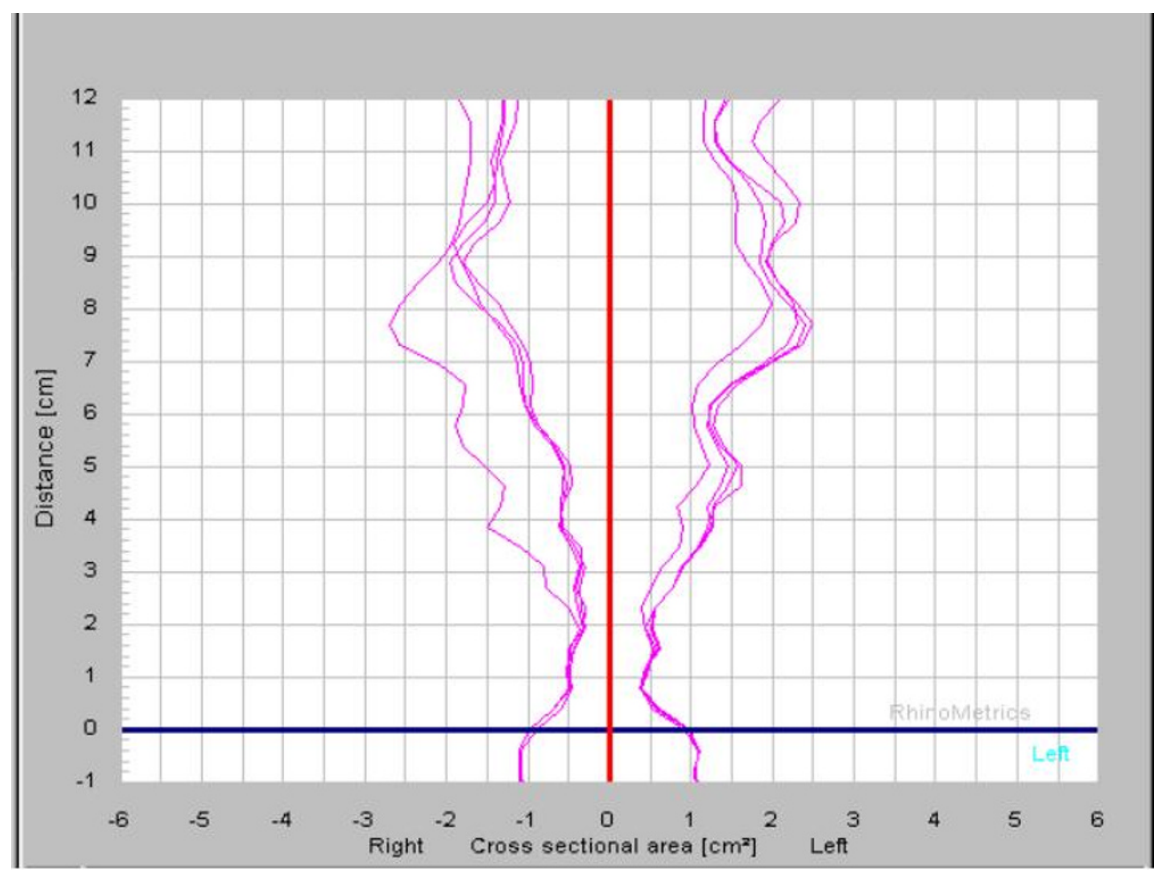

Figure 2

Acoustic Rhinometry showing changes in minimal cross-sectional area after nasal provocation test with Thyreophagus enterophagus. 
tion of wheat-containing foodstuffs, and concluded that OMA might be more prevalent in tropical and subtropical countries than previously recognized [13].

Surprisingly, our patient had also clinical history of nonsteroidal anti-inflammatory drug (NSAID) hypersensitivity, which is uncommon in children. Some authors pointed out the possible link of OMA with and NSAID hypersensitivity $[9,14,15]$. Furthermore, some other authors have hypothesized about a subset of individuals with a particular susceptibility for both OMA and NSAID hypersensitivity. Same authors hypothesized saying that drug hypersensitivity is coming first before than OMA called as a new triad [16].

In paediatric population, there events are more uncommon. Matsumoto and Satoh observed recently paediatric patients with OMA in Japan [17]. Wen et al described a paediatric case report of OMA in an 8-year-old Taiwanese, who was also co-sensitized to several mites including Dermatophagoides pteronyssinus, Dermatophagoides farinae or Blomia tropicalis. Sanchez-Borges also described a paediatric patient developed OMA [10]. As we describe above, we present the first report of anaphylaxis by Thyreophagus entomophagus in a child with previous sensitization to other mites. However, it is currently unknown the crossreactivity with other mites. More and bigger studies are needed to search this possible cross-reactivity. Using fresh new flour bags could prevent these types of events in sensitized children. Mite growing should be avoided with this simple procedure of using new bags. Alternatively, previously opened bags should be transfer to plastic bags and stored inside refrigerator to avoid high humidity and temperature, optimal conditions for mite growing [3].

\section{Competing interests}

The authors declare that they have no competing interests.

\section{Authors' contributions}

JI-S studied the case report and wrote the initial draft of the manuscript. IS-M conceived the idea and is responsible for in vivo tests. PP was responsible for the Food Allergy Section and studied the case; VI performed in vitro studies. RG is responsible for the nasal study; VM analysed the data and wrote the final version of the manuscript. All authors approved the final version of the manuscript.

\section{Acknowledgements}

Declaration of sources of funding: Víctor Matheu is recipient of a grant from "Convenio Instituto de Salud Carlos III- Comunidad Autónoma de Canarias (Programa de Intensificación de la Actividad Investigadores Clínicos 2007-20082009).

\section{References}

I. Franz JT, Masuch G, Musken H, Bergmann KC: Mite fauna of German farms. Allergy 1997, 52: I233-I237.
2. Fernandez-Caldas E, Fox RW, Bucholtz GA, Trudeau WL, Ledford DK, Lockey RF: House dust mite allergy in Florida. Mite survey in households of mite-sensitive individuals in Tampa, Florida. Allergy Proc 1990, I I:263-267.

3. Blanco C, Quiralte J, Castillo R, Ortega N, Alvarez M, Arteaga C, Barber D, Carrillo T: Anaphylaxis after ingestion of wheat flour contaminated with mites. J Allergy Clin Immunol I997, 99:308-3 I3.

4. Matheu V, Zapatero L, Alcazar M, Martinez-Molero MI, Baeza ML: IgE-mediated reaction to a banana-flavored drug additive. J Allergy Clin Immunol 2000, 106(6): I 202-I 203.

5. Radcliffe M, Scadding G, Brown HM: Lupin flour anaphylaxis. Lancet 2005, 365(9467): 1360 .

6. Alonso A, Daschner A, Moreno-Ancillo A: Anaphylaxis with Anisakis simplex in the gastric mucosa. N Engl J Med 1997, 337(5):350-35I.

7. Matsumoto T, Hisano T, Hamaguchi M, Miike T: Systemic anaphylaxis after eating storage-mite-contaminated food. Int Arch Allergy Immunol I996, 109(2): 197-200.

8. Blanco C, Castillo R, Ortega N, Alvarez M, Arteaga C, Barber D, Carrillo T: Asthma due to the ingestion of contaminated flour. J Investig Allergol Clin Immunol 1997, 7(5):323-324.

9. Blanco C, Quiralte J, Castillo R, Delgado J, Arteaga C, Barber D, Carrillo $\mathrm{T}$ : Anaphylaxis after ingestion of wheat flour contaminated with mites. J Allergy Clin Immunol 1997, 99(3):308-3I3.

10. Sanchez-Borges M, Capriles-Hulett A, Caballero-Fonesca F: Oral mite anaphylaxis (pancake syndrome) also observed in children. Ann Allergy Asthma Immunol 2006, 96(5):755-756.

II. Hannaway PJ, Miller JD: The pancake syndrome (oral mite anaphylaxis) by ingestion and inhalation in a 52-year-old woman in the northeastern United States. Ann Allergy Asthma Immunol 2008, 100(4):397-398.

12. Wen DC, Shyur SD, Ho CM, Chiang YC, Huang LH, Lin MT, Yang HC, Liang PH: Systemic anaphylaxis after the ingestion of pancake contaminated with the storage mite Blomia freemani. Ann Allergy Asthma Immunol 2005, 95(6):6 | 2-6I4.

13. Sanchez-Borges M, Capriles-Hulett A, Fernandez-Caldas E, SuarezChacon R, Caballero F, Castillo S, Sotillo E: Mite-contaminated foods as a cause of anaphylaxis. J Allergy Clin Immunol 1997, 99(6 Pt I):738-743.

14. Sanchez-Borges M, Capriles-Hulett A: Atopy and NSAID sensitivity. J Allergy Clin Immunol 1997, I00( I): I 43-144.

15. Sanchez-Borges M, Capriles-Hulett A, Caballero-Fonseca F: Additional information on the pancake syndrome. Ann Allergy Asthma Immunol 2008, I OI(2):221.

16. Sanchez-Borges M, Capriles-Hulett A, Capriles-Behrens E, Fernandez-Caldas E: A new triad: sensitivity to aspirin, allergic rhinitis, and severe allergic reaction to ingested aeroallergens. Cutis 1997, 59(6):3||-3|4.

17. Matsumoto $T$, Satoh A: The occurrence of mite-containing wheat flour. Pediatr Allergy Immunol 2004, I5(5):469-47I.

Publish with Biomed Central and every scientist can read your work free of charge

"BioMed Central will be the most significant development for disseminating the results of biomedical research in our lifetime. "

Sir Paul Nurse, Cancer Research UK

Your research papers will be:

- available free of charge to the entire biomedical community

- peer reviewed and published immediately upon acceptance

- cited in PubMed and archived on PubMed Central

- yours - you keep the copyright 